\title{
シバヤギにおける $\mathrm{PGF}_{2 \alpha}$ 投与後の末梢血中 PGF 群濃度 および $\mathrm{P}$ 濃度の動態
}

\author{
田中幹郎* ・田浦保穂・佐々木伸雄 - 山内 亮** \\ (東京大学農学部 現所属: *山口大学農学部 **日本獣医畜産大学)
}

プロスタグランジン (PG) は代謝速度が非常に速い局 所ホルモンであり, 肺循環を一度経る間にその $90 \%$ 以 上が不活化されるといわれている1。

ウシの臨床面における $\mathrm{PGF}_{2 \alpha}$ の応用は主として発情

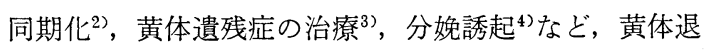

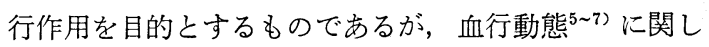
ては, 必ずしも十分検討されておらず，不明の点も多 い。

一方, 日本在来種であるシバヤギは小型で扱い易く, かつ通年発情を示すため, 最近ウシの実験モデルとして 用いられている8)。本実験においては, 性周期あるいは 妊娠期のシバャギに対して, $\mathrm{PGF}_{2 \alpha}$ を投与し，その血中 動態および投与後のプロジェステロン（P）濃度の動態 を検討した。

\section{材料と方法}

実験には, 東京大学農学部附属牧場にて繁殖・飼育さ れた雌シバヤギ 5 頭を用い, 1 頭は 2 回の実験に供した ため, のべ 6 頭を 3 頭づつ 2 群に分け, $\mathrm{PGF}_{2 \alpha}$ の筋肉内 投与群，および静脈内投与群とした。

表 1 亿両群のシバヤギの概要を示した。筋肉内投与群 の W-14 は約 2 才, 未経産で開腹によって卵巣発育不全 と判定されたものである。その後 PMS 1,000 IU を2 回投与し，その 3 カ月後に本実験に供したが，その間発 情徵候は現われなかった。B-33 は 4 才， 6 産で, 供試時

Changes of PGFs and progesterone levels in peripheral plasma of the shiba-goats after administration of $\mathrm{PGF}_{2 \alpha}$.

TANAKa, Mikio*, Yasuho TAURA, Nobuo SASAKI \& Makoto YAMAUCHI** (Department of Veterinary Surgery and Obstetrics, Faculty of Agriculture, University of Tokyo, Bunkyo-ku, Tokyo 113, Present address: *Faculty of Agriculture, Yamaguchi University, Yamaguchi-shi, Yamaguchi 735, **Nippon Veterinary and Zootechnical College, Musashino-shi, Tokyo 180)

Japan. J. Anim. Reprod., 29 (4), 1983.
に妊娠 90 日目であった。R-42も4才，6産で同じく妊 娠 95 日目であった。

一方, 静脈内投与群 3 頭のうち, W-14 は筋肉内投与 実験に用いたシバャギと同一のものであり, 筋肉内投与 実験後 1 カ月を経過して本実験に用いたが，その時まで に発情徵候は認められなかった。B-21 は 3 才, 2 産で, 実験前に少なくとも 3 回正常な 21 日の発情周期を繰り 返しており, 次回発情予定日の 4 日前に本実験に供し た。B-50 は 3 才, 1 産で, 実験前少なくとも 3 回正常 な発情を繰り返しており, 発情開始後 3 日目に本実験に 供した。

これらの 2 群に対し, $\mathrm{PGF}_{2 \alpha}$ (パナセラン, 富士薬品 工業株式会社） $3 \mathrm{mg}$ を筋肉内投与群には䌓筋内へ，静 脈内投与群は頸静脈へ投与した。末梢血中 PGF 群濃度 および $\mathrm{P}$ 濃度測定用の血液は筋肉内投与群では投与前 24 時間, 1 時間, 投与直後 (0 分), 10 分, 20 分, 40 分, 80 分, 3 時間, 5 時間, 10 時間, 24 時間, および 48 時間に採取した。また，静脈内投与群における採血は， 投与前 1 時間, 投与直後 ( 0 分), 1 分, 2 分, 5 分, 10 分, 15 分, 20 分, 25 分, 30 分, 45 分, 1 時間, 2 時 間, 4 時間, 16 時間, および 48 時間に行った。採血は, $\mathrm{PGF}_{2 \alpha}$ の投与に用いた頸静脈と反対側の頸静脈内に, 予 め留置したポリエチレン製のカテーテル（アーガイル社 製，血管留置用カテーテル，18G，長さ $30 \mathrm{~cm}$ ) を通して 行った。また, 採取血液はへパリン加血とし, 採取後 直ちに 2,500 rpm 20 分遠心分離して血漿を分離し, $-20^{\circ} \mathrm{C}$ で保存した。

PGF 群濃度の测定は著者らがすでに報告した方法9 に従い, 血漿 $10 \mathrm{~m} l$ から PGF 群を抽出, 分離した後, RIA で行った。また， P濃度の測定は，百目鬼らの方 法 ${ }^{10)}$ に順じ, RIA で行った。

\section{結果}

1. $\mathrm{PGF}_{2 \alpha} 3 \mathrm{mg}$ の筋肉内投与群 3 頭に扩ける, 末梢血 中 PGF 群およびP濃度の動態はそれぞれ図 $1,2,3$ に 
Table 1. Experimental goats

\begin{tabular}{ccccl}
\hline \hline Treatment & No. & Age & Partus & \multicolumn{1}{c}{ Status } \\
\hline \multirow{3}{*}{ im injection of $\mathrm{PGF}_{2 \alpha}$} & W-14 & $?$ & 0 & Ovarian hypoplasia \\
& $\mathrm{B}-33$ & 4 & 6 & Pregnancy (90 days) \\
& $\mathrm{R}-42$ & 4 & 6 & Pregnancy (95 days) \\
\hline \multirow{3}{*}{ iv in jection of $\mathrm{PGF}_{2 \alpha}$} & W-14 & $?$ & 0 & Ovarian hypoplasia \\
& $\mathrm{B}-21$ & 3 & 2 & Late luteal phase \\
& $\mathrm{B}-50$ & 3 & 1 & 3 days after onset of estrus \\
\hline
\end{tabular}

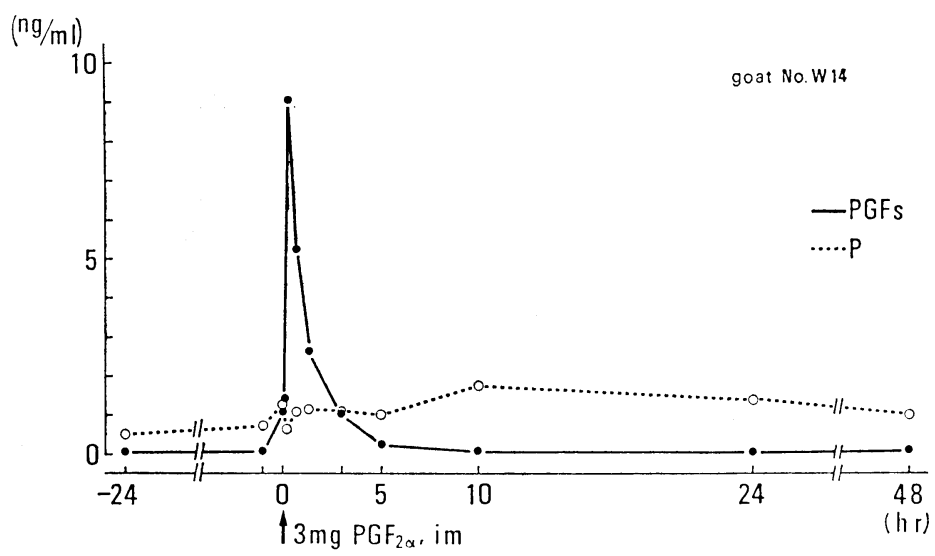

Fig. 1. PGFs and $P$ levels in peripheral plasma after im injection of $\mathrm{PGF}_{2 \alpha}$.

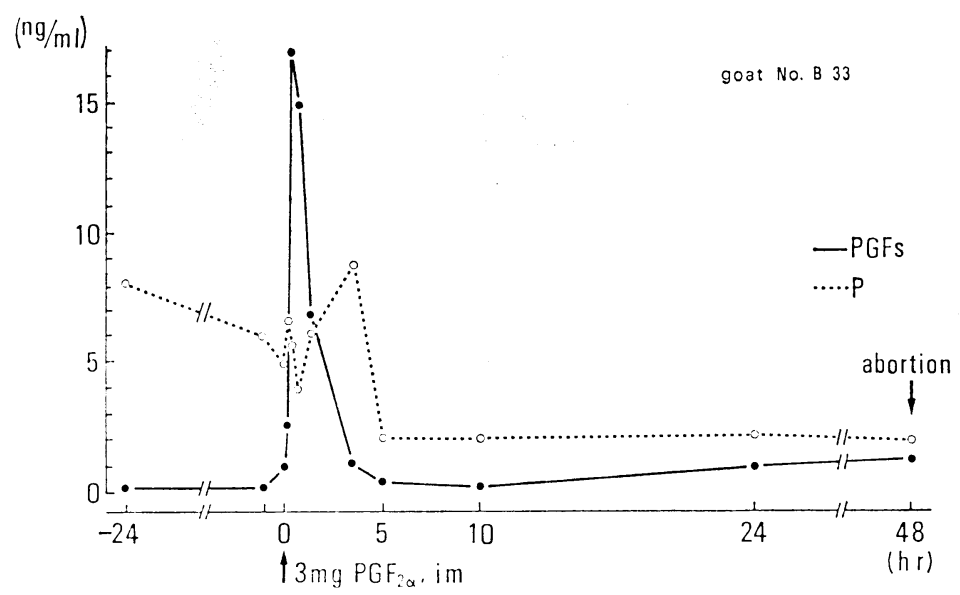

Fig. 2. $P G F$ s and $P$ levels in peripheral plasma after im injection of $\mathrm{PGF}_{2 \alpha}$.

示した。

$\mathrm{PGF}$ 群濃度は, $\mathrm{PGF}_{2 \alpha}$ の投与後急激に上昇し, 20 分 で, W-14 は $9 \mathrm{ng} / \mathrm{ml}, \mathrm{B}-33$ は $16.7 \mathrm{ng} / \mathrm{ml}, \mathrm{R}-42$ は $7.7 \mathrm{ng} / \mathrm{m} l$ のピークを示したが，その後は急速に低下し
て 5 時間後までにはほぼ前値へ復した。 非妊娠の W-14 と扮いて処置後の PGF 群濃度は, 10 時間, 24 時間, 48 時間後にいずれる処置前とほぼ同濃 度の $100 \mathrm{pg} / \mathrm{m} l$ 以下を示したが, 妊娠していた B-33,

$$
-172-
$$




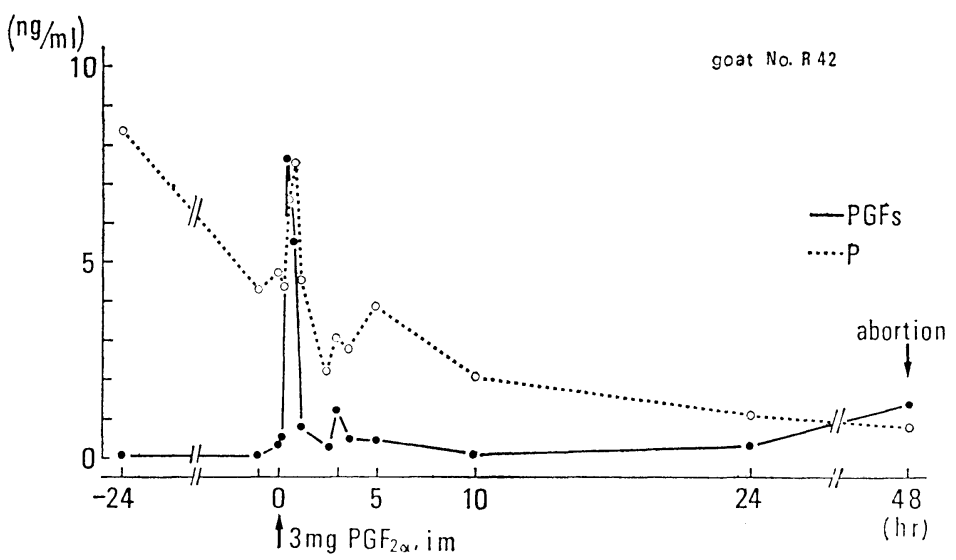

Fig. 3. $P G F s$ and $P$ levels in peripheral plasma after im injection of $\mathrm{PGF}_{2 \alpha}$.

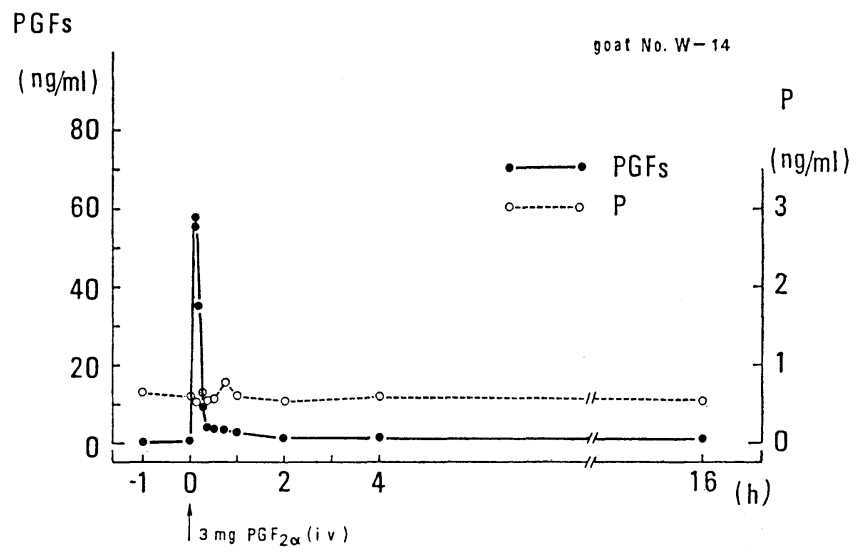

Fig. 4. PGFs and $P$ levels in peripheral plasma after iv injection of $\mathrm{PGF}_{2 \alpha}$.

$\mathrm{R}-42$ の 2 頭においては, 10 時間後に最低值を示した後 24 時間, 48 時間と時間の経過に伴って徐々に濃度を増 す傾向が認められ，48 時間後にはそれぞれ $1.1 \mathrm{ng} / \mathrm{ml}$ および $1.4 \mathrm{ng} / \mathrm{m} l$ を示した。これらの 2 頭は処置後 2 日目に流産し，B-33 は 5 頭, R-42 は 3 頭の胎仔がそれ ぞれ確認された。なお, B-33 は, 流産後外陰部からの 出血が異常に多く, また, 血小板数が 8,000 個 $/ \mathrm{mm}^{3}$ で あり，TEG 所見からも血液凝固不全が疑われた。翌日 になって死亡したため, 剖検した結果, 子宮は腫大し, 部分的壊死とガスの貯溜が認められた。また, 腎蔵の点 状出血, 左心室内膜, 大網膜叔よび脳室の出血が認めら れたことから, 血小板減少を伴う血液凝固不全, たとえ ば DIC (disseminated intravascular coagulation)の 発生が示唆された。
R-42 においても, 流産後外陰部からのわずかな出血 が続き, 軽度の貧血が認められたものの, 血小板数に異 常は認められなかった。この例では, 抗生物質, 止血剂, 子宮収縮剂の投与により 1 週間後には元気, 食欲とも正 常に復した。

一方, $\mathrm{PGF}_{2 \alpha}$ 筋注後の $\mathrm{P}$ 濃度の变動に関しては, W14 において処置前に $0.6 \mathrm{ng} / \mathrm{m} l$ と非常に低く, 黄体の 発育のきわめて乏しいことが示され, 開腹による卵巣発 育不全の所見を裏付けるものであった。また， $\mathrm{PGF}_{2 \alpha}$ 投 与により多少の変動は見られたものの, 全般的には大き な変動は認められなかった（図 1 )。他の 2 頭は, 妊娠中 期であり, 処置時には $5 \mathrm{ng} / \mathrm{m} l$ と高濃度を示した。処置 直後はいずれも一過性に $\mathrm{P}$ 濃度は上昇したが，その後短 時間のらちに処置前の濃度以下に低下した。以後数時間 


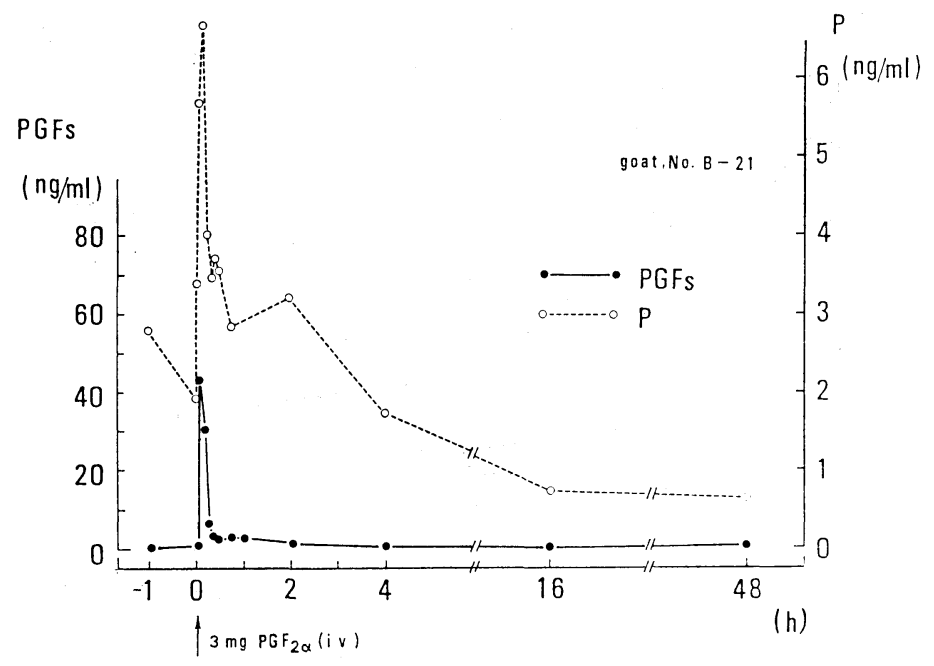

Fig. 5. PGFs and $P$ levels in peripheral plasma after iv injection of $\mathrm{PGF}_{2 \alpha}$.

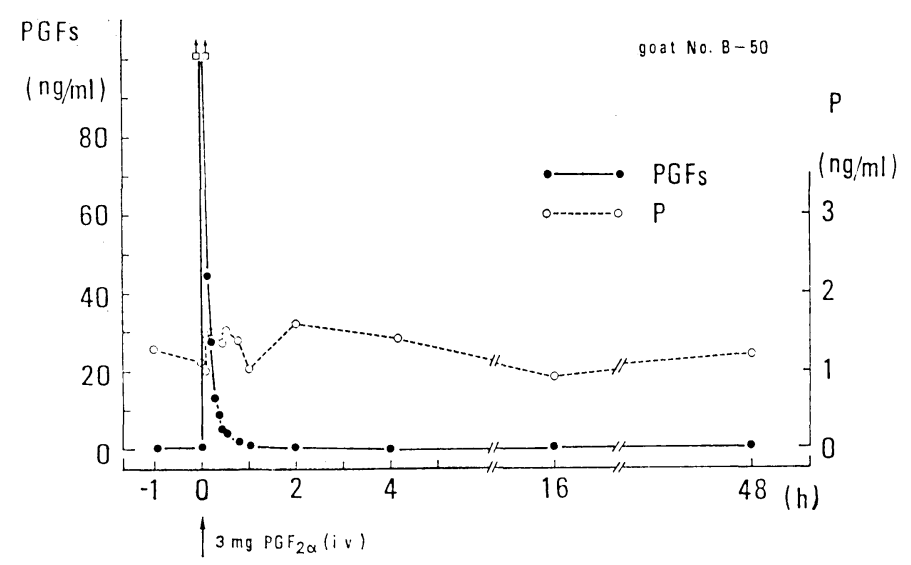

Fig. 6. PGFs and $P$ levels in peripheral plasma after iv injection of $\mathrm{PGF}_{2 \alpha}$.

を経て再び上昇してピークを形成したが，その後は徐々 に低下を続け，48 時間前後で流産が認められた。

2. $\mathrm{PGF}_{2 \alpha} 3 \mathrm{mg}$ の静脈内投与群 3 頭における, 末梢 血中 PGF 群および $\mathrm{P}$ 濃度の動態はそれぞれ図 $4,5,6$ に示した。

W-14 においては, $\mathrm{PGF}_{2 \alpha}$ 処置後 1 分, 2 分および 48 時間の採血が行えなかったが，3頭のいずれも血中 PGF 群濃度は投与後急激に上昇し， 5 分以内に最高值 (W-14：58 ng/ml, B-21：48 ng/ml, B-50：少なくとも $100 \mathrm{ng} / \mathrm{ml})$ に達し, その後急速に低下した。PGF 群濃 度のピークが少なくとも $100 \mathrm{ng} / \mathrm{m} l$ の高濃度を示した
B-50 においては 30 分後, 他の 2 頭は 20 分後に $5 \mathrm{ng}$ / $\mathrm{m} l$ 以下に下降した。その後 $\mathrm{PGF}$ 群濃度は徐々に低下 し, 約 2 時間後には投与前値に復した。

一方 P濃度に関しては, 卵巣発育不全の W-14 におい て, $\mathrm{PGF}_{2 \alpha}$ 投与後多少の変動はみられたが, 全般的には 筋肉内投与の場合と同様に大きな変動は認められなかっ た（図 4 ）。発情予定日の 4 日前に処置した B-21 に拉 いては, 処置後 $\mathrm{P}$ 濃度は急激な上昇を示した。すなわち, 10 分後に処置前値の約 4 倍に達し, “次いで急激に低下し た後，2時間で再び軽度のピークを形成し，以後緩やか に低下した。発情後 3 日で, 黄体が未だ十分に発達して 
いないと思われる時期沉処置した B-50 においては，処 置後 $\mathrm{P}$ 濃度は上昇したものの, B-21 に比べ低く, かつ そのピークは 1 時間にわたって持続した。処置後 2 時間 で B-21 と同様に第 2 のピークを示したのち 16 時間後 まで徐々に低下した。しかし，48 時間後には再び軽度の 上昇が認められた。

\section{考察}

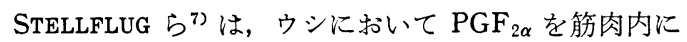
投与した場合, PGF 群濃度は 10 分以内に最高值に達 し，90 分以内にもとのレベルに復すと報告している。今 回の実験で用いたシバヤギにおいては, PGF 群濃度が ピークを示すのは処置後 20 分と, ウシに比較してやや 遅く, またその後の動態も処置後 90 分までは急激な低 下を示すものの, 処置前値に復すには約 5 時間を要する ことが認められた。

一方, 静脈内投与群において, 未梢血中 PGF 群濃度 の最高値は, 筋肉内投与群の約 10 倍に達するが, その 低下は非常に速く, 30 分以内には $5 \mathrm{ng} / \mathrm{m} l$ 以下に低下 した。しかし, 処置前值への回復には筋注群と同様, ウ シで報告されている 15 分以内とは異なり， 2 時間を要 した。これらのことから，シバヤギにおいては肺におけ る代謝速度がウシよりも遅いことが示唆された。一方, STELLFLUG ら ${ }^{12)}$ によれば， $\mathrm{PGF}_{2 \alpha}$ の投与量の違いによ っても $\mathrm{PGF}_{2 \alpha}$ の代謝時間に差のあることが認められて おり，今後シバヤギにおいても投与量を変化させて検討 する必要があると思われた。

外因性 $\mathrm{PGF}_{2 \alpha}$ の黄体に対する退行作用は, 妊娠黄体 に対しても強力で, $3 \mathrm{mg} 1$ 回の筋肉内投与により, 急 激な $\mathrm{P}$ 分泌低下を引き起こし, 2 日後に流産を生じさせ た。

$\mathrm{PGF}_{2 \alpha}$ 投与後, $\mathrm{P}$ 濃度は低下したが, その過程で 2 度 のピークを形成した。第 1 のピークは, 筋肉内投与群で 処置後 20 分までに, 静脈内投与群で 10 分までに認め られ，その後急激に低下した。第 2 のピークは，筋肉内 投与群で処置後 3 4 時間, 静脈内投与群で 2 時間後に 認められた。しかし第1のピークは, 頻回採血を行わな かった例で認められない場合があった。この第 1 のピー クに対し, STELLFLUG ら ${ }^{11}$, SPEROFF $ら^{12}$ は $\mathrm{PGF}_{2 \alpha}$ の 黄体細胞に㧍けるPの合成刺激をその理由として推測し た。一方, OKAMURA ら ${ }^{13)}$ は, 七卜黄体外鞘中に存在する 平滑筋が $\mathrm{PGF}_{2 \alpha}$ により顕著に収縮することを認めてい るが， $\mathrm{PGF}_{2 \alpha}$ 投与直後の $\mathrm{P}$ 濃度上昇は非常に速いこと から，シバヤギにおいては，この平滑筋收縮に伴う黄体
中のPの放出によるものではないかと考えられた。

第 1 のピークは, 持続することなく短時間で低下した が,これに関しては THORBURN ら ${ }^{14)}$ の示した $\mathrm{PGF}_{2 \alpha}$ の 局所的な血管収縮作用によるものと考兄られた。

さらに第 2 のピークに関しては STELLFLUG ら ${ }^{11) か ゙ ~}$ $\mathrm{PGF}_{2 \alpha}$ の投与 2 3 時間後に血中 $\mathrm{LH}$ 濃度の上昇を認 め, 第 2 のピークをこれによるるのと推測しており, 今 回シバヤギの例もほぼ同様の理由によると思われる。

一方, 筋肉内投与群の妊娠中期のシバヤギ 2 頭におい て, $\mathrm{PGF}_{2 \alpha}$ 投与の 2 日後に流産が引き起こされた。この 2 例に打ける処置後 48 時間の末梢血中 PGF 群濃度は, 処置前および処置後 24 時間のそれらより高いことが認 められた。この処置後 48 時間の PGF 群濃度の上昇は, 外因性の $\mathrm{PGF}_{2 \alpha}$ によるものではなく, なんらかの要因 により分泌された内因性の $\mathrm{PGF}_{2 \alpha}$ によるものと考えら れ，流産との関連も考えられるが, $\mathrm{PGF}_{2 \alpha}$ の投与により 生じる黄体退行に伴って, エストラジオールの分泌が促 進されることが認められており ${ }^{15)}$ ，今後オキシトシン， コーチゾルなどを含めてさらに検討を重ねる必要があろ ら。

さて $\mathrm{PGF}_{2 \alpha}$ 処置による流産後, 1 例は血小板減少を 伴う血液凝固不全を呈して死亡した。PG の中には血小 板汶し, 凝集抑制作用 ${ }^{16,17)}$ および凝集促進作用 ${ }^{18)}$ を示 するのがあるが， $\mathrm{PGF}_{2 \alpha}$ にこのような血小板に対する 作用は認められていない。したがって $\mathrm{PGF}_{2 \alpha}$ 投与後の 流産時に認められた血小板減少性の出血傾向穴進は,

$\mathrm{PGF}_{2 \alpha}$ の直接作用ではなく, 流産後に生じたなんらか の要因, 例妄ば子宮の血行障害, 細菌感染, 組織の壊死 およびそれに起因したショック状態が DICを誘発し た ${ }^{19)}$ ものではないかと考兄られた。

$\mathrm{PGF}_{2 \alpha}$ の静脈内投与群に打いては, 3 頭とも性周期の 異る時期に処置したが, $\mathrm{PGF}_{2 \alpha}$ に対する黄体の反応に差 のあることが認められた。すなわち黄体の存在しないと 考えられるW-14 においては, 処置後の $\mathrm{P}$ 濃度にほとん ど変化がみられなかった。一方黄体後期の B-21 飞おい ては, 処置後 $\mathrm{P}$ 低下の前に一過性に顕著な $\mathrm{P}$ 濃度の上昇 が認められたが，これが前述した黄体外鞘中の平滑筋収 縮によるものと考えれば, 黄体内に貯溜している $\mathrm{P}$ 量の 多いことを示するのと思われた。他方, 発情開始後 3 日 目で黄体の形成が完全でないと考えられる B-05 亿执い ては, 処置後の $\mathrm{P}$ 濃度上昇は著明ではなく, 黄体内に貯 溜された $\mathrm{P}$ 量が多くないことが推察された。また，第 2 のPのピーク以後 B-21 に打いては 48 時間まで徐々に 低下してゆくのに反し，B-50 に打いては 16 時間後の 
$\mathrm{P}$ 濃度に比較して 48 時間後の $\mathrm{P}$ 濃度が高くなっており, 48 時間以降は検討していないため, 必ずしも明らかでは ないが，この例では黄体は退行することなく再び発育す る可能性を示すむのと考えられる。このことは，この B-50 に拈いて次回の発情が前回の発情の 20 日後に認 められ，性周期に変化のなかったことからも裏付けられ た。百目鬼ら ${ }^{20)}$, 中原ら ${ }^{3)}$, HENRICKS $5^{21)}$ を初め多くの 研究者が， $\mathrm{PGF}_{2 \alpha}$ 投与によるウシの性周期の 同期化に おいて同様のことを報告しており, $\mathrm{PGF}_{2 \alpha}$ は機能的な黄 体に対しては，その退行作用は顕著であるが，発㕕過程 の新生黄体に対しては，その作用を示さないか，あるい は一時的に退行作用は示しても $\mathrm{PGF}_{2 \alpha}$ の血中濃度が低 下すると再び黄体は発育すると考えられた。

\section{要 約}

通年発情を示す日本在来種のシバヤギに対して $\mathrm{PGF}_{2 \alpha} 3 \mathrm{mg}$ を筋肉内ならびに静脈内投与し, その末梢 血中動態および投与後の末梢血中 $\mathrm{P}$ 濃度の動態を検討し た。

1. 筋肉内投与群において PGF 群濃度は投与後急激 に上昇し, 20 分で最高值 $(9 \mathrm{ng} / \mathrm{ml}, 16.7 \mathrm{ng} / \mathrm{ml}, 7.7$ $\mathrm{ng} / \mathrm{m} l)$ を示すが，その後は急速に低下して 5 時間後ま でにはもとの襄度に復した。いっぽう，静脈内投与群に おいては処置後急激に上昇し， 5 分以内に最高值 (58 $\mathrm{ng} / \mathrm{m} l, 48 \mathrm{ng} / \mathrm{ml}, 100 \mathrm{ng} / \mathrm{m} l<)$ に達し, その後急速に 低下するが，処置前の濃度に復するには約 2 時間を要し た。これら 2 つの群における PGF 群濃度が処置前の濃 度に復すに要する時間は, ウシにおける STELLFLUG ら の報告に比較して多少長いことが認められたものの, シ バヤギにおいても $\mathrm{PGF}_{2 \alpha}$ の代謝時間は非常に短かいこ とが認められた。

.2. $\mathrm{PGF}_{2 \alpha}$ の黄体に及ぼす影響に関しては, 妊娠中期 の黄体に対して，図 2，3 で示す通り顕著な $\mathrm{P}$ 分泌の抑 制が認められ，処置後 2 日目に流産を引き起こした。性 周期の異なる時期，すなわち退行期の黄体と新生黄体と では図 5, 6 に示す通り $\mathrm{PGF}_{2 \alpha}$ に対する感受性に差が認 められ, 黄体退行期には $\mathrm{PGF}_{2 \alpha}$ の処置により顕著な $\mathrm{P}$ 濃度の低下を示した。しかし黄体新生期には処置後一時 的に $\mathrm{P}$ 濃度は低下寸るが再び上昇する傾向が認められ， しかも次回の発情が早まることなく正常な周期で発現し た。このことからシバャギの新生黄体は百目鬼ら，中原 ら, HENRICKS らがウシで認めていると同様に, PGF $2 a$ に対する感受性が低いものと推定された。

3. $\mathrm{PGF}_{2 \alpha}$ 投与後の $\mathrm{P}$ 濃度の変化は, 投与直後および
筋肉内投与群に拈いては $4 \sim 5$ 時間後, 静脈内投与群に おいては 2 時間後の 2 回，それぞれピークを形成するこ とが認められた。第1のピークに関しては, OKAMURA らがヒト黄体で認めているように, $\mathrm{PGF}_{2 \alpha}$ が黄体外鞘中 の平滑筋に作用しこれを収縮させる結果生じたと推察さ れた。

(1983. 5. 15 受付)

\section{文献}

1) EERREIRA, S. H. \& J. R. VANE: Nature, 216 , 868, 1967.

2) Rowson, L. E. A., R. Tervit \& A. Brand: J. Reprod. Fert., 29, 145, 1972.

3) 中原 (達)：日獣会誌, 29, 51, 1976.

4) 中原 (達) - 百目鬼 (郁) - 金田 (義) - 加茂前 (秀)： 本誌, 21, 135, 1975.

5) Nancarrow, C. D., J. Buckmaster, W. Chamley, R. I. Cox, I. A. Cumming, L. Cummins, W. SCHNEIDER \& G. D. ThORBURN: J. Reprod. Fert., 32, 320, 1973.

6) Fairclough, R. J., J. T. Hunter \& R. A.S. WELCH: Prostaglandins, 9, 901, 1975.

7) Stellflug, J. N., T. M. Louis, H. D. Hafs \& B. E. Seguin: Prostaglandins, 9, 609, 1975.

8) Kano, Y., T. SaWASAKI \& T. OYama: Exp. Anim., 26, 239, 1977.

9) 田中 (幹) ・田浦 (保) ・佳々木 (伸) - 山内 (亮)：本 誌, 29, 140, 1983.

10)百目鬼 (郁) - 中原 (達) - 山内 (亮)：本誌， 20, 95, 1974.

11) Stellflug, J. N., T. M. Louis, R. C. GoRewit, W. D. OXENDER \& H. D. HAFS: Biol. Reprod., 17, 535, 1977.

12) Speroff, L. \& P. W. Ramwell: J. Clin. Endocrinol. Metab., 30, 345, 1970.

13) OKamura, H., T. OKaZaki \& A. NaKajima: Obstet. Gynec., 44, 720, 1974.

14) Thorburn, G. D. \& J. R. S. Hales: Proc. Aust. Physiol. Pharm. Soc., 3, 145, 1972.

15) Hixon, J. E. \& W. Hansel: Biol. Reprod., 11, $543,1974$.

16) KloEze, J.: Prostaglandins, Proceedings of the 2nd nobel symposium (BERGström, S. \& G. D. THORBURN, ed.) p. 241, Interscience, 1967.

17) Moncada, S., R. Gryglewski, S. Bunting \& J. R. VANE: Nature, 263, 663, 1976.

18) Namberg, M., J. Svensson, T. Wakabayashi \& B. Samuelsson: Proc. Nat. Acad. Sci. USA. 71, 345, 1974.

19) 真木 (正)：臨床病理，臨時増刊特集第 32 号, 3 , 1978. 
20)百目鬼 (郁) - 中原 (達) - 金田 (義) - 山内 (亮)：本 誌, 21, 89, 1975.
21) HENRICKS, D. M., J. T. LONG, J. R. HILL \& J. F. Dickey: J. Reprod. Fert., 41, 113, 1974.

\section{Summary}

Concentrations of PGFs and progesterone in peripheral plasma of shiba-goats (small Japanese native goats with non-seasonal estrous cycles) injected with PGF $_{2 \alpha}$ were determined by RIA. After intra-muscular injection of $3 \mathrm{mg} \mathrm{PGF}$, , plasma PGFs levels .reached to the peak $(9 \mathrm{ng} / \mathrm{m} l, 16.7 \mathrm{ng} / \mathrm{m} l$, $7.7 \mathrm{ng} / \mathrm{ml}$ ) at $20 \mathrm{~min}$, post-injection, and then decreased rapidly. It took about $5 \mathrm{~h}$ for PGFs levels to resume the primary levels as shown in Figs. 1, 2 and 3.

On the other hand, after intra-venous injection of $3 \mathrm{mg} \mathrm{PGF} 2 \alpha$, plasma PGFs levels reached to the peak within $5 \mathrm{~min}$ and then decreased rapidly. It took about $2 \mathrm{~h}$ for PGFs levels to resume the primary levels (Figs. 4, 5 and 6). From these results, the metabolic time of $\mathrm{PGF}_{2 \alpha}$ in the shiba-goat was very short, though it was a little longer than that in cattle reported by STELLFLUG et al.

Luteolytic effect of $\mathrm{PGF}_{2 \alpha}$ was found to be very remarkable in pregnant goats (Figs. 2 and 3), both of which aborted 2 days after intra-muscular injection. In estrous cycles, however, sensitivity of corpus luteum to $\mathrm{PGF}_{2 \alpha}$ depended on the stage of the luteal phase. During late luteal phase, plas. ma progesterone levels decreased markedly after PGF $_{2 \alpha}$ injection (Fig. 5). On the contrary, during early luteal phase (Day 3), progesterone levels decreased in just short period after injection, and in. creased again to initial levels (Fig. 6)

Two peaks were found in the plasma progesterone levels after PGF $_{2 \alpha}$ injection. The first peak appeared shortly after injection and the second appeared $4-5 \mathrm{~h}$ later in intra-muscular injection group and $2 \mathrm{~h}$ later in intravenous injection group. The first peak might be caused by the contraction of capsules of the corpus luteum by direct action of $\mathrm{PGF}_{2 \alpha}$ as known in humans. 